Boston University School of Law

Scholarly Commons at Boston University School of Law

Faculty Scholarship

2007

\title{
A Search-Costs Theory of Limiting Doctrines in Trademark Law
}

Stacey Dogan

Boston Univeristy School of Law

Follow this and additional works at: https://scholarship.law.bu.edu/faculty_scholarship

Part of the Law Commons

\section{Recommended Citation}

Stacey Dogan, A Search-Costs Theory of Limiting Doctrines in Trademark Law, 97 The Trademark Reporter 65 (2007).

Available at: https://scholarship.law.bu.edu/faculty_scholarship/665

This Article is brought to you for free and open access by Scholarly Commons at Boston University School of Law. It has been accepted for inclusion in Faculty Scholarship by an authorized administrator of Scholarly Commons at Boston University School of Law. For more information, please contact lawlessa@bu.edu. 


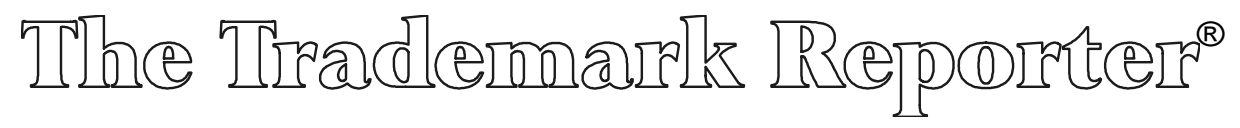

Official Journal of the International Trademark Association

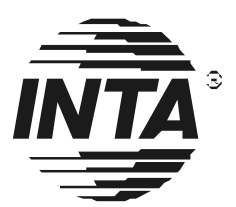

A Search-Costs Theory of Limiting Doctrines in Trademark Law By Stacey L. Dogan and Mark A. Lemley

The Trademark Dilution Revision Act of 2006:

Balanced Protection for Famous Brands By Scot A. Duvall

Literal Falsity by Necessary Implication: Presuming Deception Without Evidence in Lanham Act False Advertising Cases By Richard J. Leighton

Sophistication and the Sciences By Jerre B. Swann

Patents Compared to Trademarks:

The Duty of Candor/The Avoidance of Fraud

By Tamsen Valoir and Professor David Hricik

Phoenix of Broward, Inc. v. McDonald's Corporation: Judicious Application of the Doctrine of Prudential Standing, or Unjustified Abstention from the Proper Exercise of Jurisdiction? By Griffith B. Price, Jr.

Are Identical Marks in the Same Field of Services Likely to Be

Confused? Omicron Capital, LLC v. Omicron Capital, LLC By Heather L. Jensen

An Introduction to the

New Trademark Trial and Appeal Board Rules

By James R. Robinson and Kathleen E. McCarthy

Amicus Brief of the International Trademark Association in adidas $A G$ and adidas Benelux BV v Marca Mode, C\&A Nederlanden, H\&M Hennes \& Mauritz Nederlands BV and Vendex $K B B$ Nederlanden $B V$ 


\title{
A SEARCH-COSTS THEORY OF LIMITING DOCTRINES IN TRADEMARK LAW*
}

\author{
By Stacey L. Dogan ${ }^{* *}$ and Mark A. Lemley ${ }^{* * *}$
}

\section{INTRODUCTION}

Twenty years have passed since William Landes and Richard Posner wrote their classic economic defense of trademark laws. ${ }^{1}$ Under Landes and Posner's "search costs" theory, trademarks have value because they reduce consumer search costs and thus promote overall efficiency in the economy. Over the past two decades, the search costs theory of trademark law has attracted a substantial following among both commentators and courts. ${ }^{2}$

While the search costs theory provides a compelling argument for trademark rights, it also compels an equally important-but often overlooked-set of principles for defining and limiting those rights. Certainly, trademark laws can make it easier and cheaper for consumers to locate products with desired qualities, thus

* C 2007 Stacey L. Dogan \& Mark A. Lemley. This paper is a continuation of a larger project on trademarks, and portions of the text are adapted from our article Trademarks and Consumer Search Costs on the Internet, 41 Hous. L. Rev. 777 (2004) [hereinafter Dogan \& Lemley, Search Costs]. This article originally appeared in Trademark Law and Theory: A Handbook of Contemporary Research (Dinwoodie \& Janis eds. 2007). Thanks to Graeme Dinwoodie, Eric Goldman, Rose Hagan, Laura Heymann, Justin Hughes, Mark Janis, Ariel Katz, Doug Lichtman, Peter Menell, Michael Meurer, Sandra Rierson, Peter Swire, Rita Weeks and participants in workshops at the 2004 IPIL/Houston Santa Fe Conference: Trademark in Transition, Boston University Law School, the Intellectual Property Scholars' Conference at DePaul College of Law, George Washington University National Law Center, Stanford Law School, Thomas Jefferson School of Law, and the University of San Diego Law School for discussions and comments on this or that earlier project.

** Professor of Law, Northeastern University School of Law.

*** William H. Neukom Professor of Law, Stanford Law School; of counsel, Keker \& Van Nest LLP.

1. William M. Landes \& Richard A. Posner, Trademark Law: An Economic Perspective, 30 J. L. \& Econ. 265 (1987).

2. E.g., Qualitex Co. v. Jacobson Prods. Co., 514 U.S. 159, 163-64 (1995); Brennan's, Inc. v. Brennan's Restaurant, L.L.C., 360 F.3d 125, 132 (2d Cir. 2004); Ty Inc. v. Perryman, 306 F.3d 509 (7th Cir. 2002); New Kids on the Block v. News Amer. Pub., Inc., 971 F.2d 302, 305 \& n.2 (9th Cir. 1992); Clarisa Long, Dilution, 106 Colum. L. Rev. 1029, 1056-59 (2006); Maureen A. O'Rourke, Defining the Limits of Free-Riding in Cyberspace: Trademark Liability for Metatagging, 33 Gonz. L. Rev. 277, 306-07 \& n 114 (1997); Margreth Barrett, Internet Trademark Suits and the Demise of "Trademark Use," 39 U.C. Davis L. Rev. 371, 376-78 (2006). But see Mark P. McKenna, The Normative Foundations of Trademark Law, 82 Notre Dame L. Rev. 1839 (2007) (challenging search costs rationale and pointing to an amorphous concept of unfair competition as the predominant driving force behind trademark law). 
making markets more competitive. Yet if carried too far, trademark law can do the opposite: it can entrench market dominance by leading firms and make it harder for competitors to crack new markets. The evolution of trademark law reflects a continual balancing act that seeks to maximize the informational value of marks while avoiding their use to suppress competitive information.

Most of the literature on the search costs theory of trademark law has focused on the theory as a rationale for trademark protection. In this article, we examine its role in supporting limiting doctrines in trademark law. ${ }^{3}$ Some limiting doctrines unambiguously lower consumer search costs and thus promote the goals of trademark law. Another group of doctrines, however, involves behavior that increases consumer search costs for some individuals even as it improves economic conditions for others. These latter doctrines-genericness, functionality, and abandonment-may sometimes go too far in accepting increased consumer search costs as the cost of achieving competition. Rather than the all-or-nothing approach suggested by these doctrines, the authors suggest that consumers would benefit from a more nuanced approach in their application.

\section{TRADEMARKS AND INFORMATION}

\section{A. Economic Theory-Trademarks and Search Costs}

Most people think of trademark law in terms of what it forbids: the use of another party's trademark, or something resembling it, in a way that will cause confusion among consumers in the marketplace. Courts commonly describe the goal of trademark law as avoiding consumer confusion, which has the corollary effect of preventing the appropriation of a producer's goodwill. ${ }^{4}$ Both consumers and producers, these courts point out,

3. By and large, these limiting doctrines are defenses. However, some of the doctrines we discuss here have a more complex relationship to the prima facie case of trademark infringement. There is controversy over whether the trademark use requirement is a defense or a part of the trademark owner's affirmative case, for example, and the doctrine of functionality is sometimes a defense and sometimes a part of the prima facie case, depending on which section of the Lanham Act is invoked. We have chosen the term "limiting doctrines" to avoid any confusion on this point. We also wish to make it clear that we have chosen only a subset of those doctrines for discussion in this paper.

4. See, e.g., Park 'N Fly, Inc. v. Dollar Park \& Fly, Inc., 469 U.S. 189, 197-98 (1985) (noting that the goal of trademark protection is to protect the consumer's ability "to distinguish among competing producers"); Ty Inc. v. Perryman, 306 F.3d 509, 510 (7th Cir. 2002) (noting that the central concern of trademark law is to provide consumers with "a concise and unequivocal identifier of the particular source of particular goods"). 
benefit when the public has access to truthful information about the source of products and services. ${ }^{5}$

In economic terms, trademarks contribute to economic efficiency by reducing consumer search costs. ${ }^{6}$ Rather than having to inquire into the provenance and qualities of every potential purchase, consumers can look to trademarks as shorthand indicators. Because this short-hand information is less expensive than detailed inquiries, consumers can more easily obtain and process it and will arguably become better informed, resulting in a more competitive market. ${ }^{7}$ This system works, of course, only if

5. See Qualitex, 514 U.S. at 163-64; Park 'N Fly, 469 U.S. at 197-98 (considering the benefits to consumers and producers that motivated Congress to pass the Lanham Act); Perryman, 306 F.3d at 510.

6. See William M. Landes \& Richard A. Posner, The Economic Structure of Intellectual Property Law 167-68 (2003); Nicholas S. Economides, The Economics of Trademarks, 78 TMR 523, 525-27 (1988) (discussing the economic benefits of marks that apprise consumers of products' unobservable features); Nicholas S. Economides, Trademarks, in 3 The New Palgrave Dictionary of Economics and the Law 602 (Peter Newman ed., 1998) [hereinafter Economides, Trademarks] (describing the savings for consumers in product searches as one of "[t]he primary reasons for the existence and protection of trademarks"); Brian A. Jacobs, Trademark Dilution on the Constitutional Edge, 104 Colum. L. Rev. 161, 164 (2004) (noting search costs rationale); Landes \& Posner, supra note 1, at 268-70 (identifying the lowering of brand recognition costs to consumers as the justification for trademark law); Mark A. Lemley, The Modern Lanham Act and the Death of Common Sense, 108 Yale L.J. 1687, 1690-94 (1999) [hereinafter Lemley, Modern Lanham Act] (describing economic justifications for trademarks and advertising); I.P.L. Png \& David Reitman, Why Are Some Products Branded and Others Not? 38 J.L. \& Econ. 207, 208-11, 218 (1995) (analyzing empirical search cost data and suggesting that "consumers of products subject to performance uncertainty will pay for brand-name assurance"); John F. Coverdale, Comment, Trademarks and Generic Words: An Effect-on-Competition Test, 51 U. Chi. L. Rev. 867, 869-70 (1984) (noting that trademark law encourages competition, which potentially decreases the cost to consumers); see also Qualitex, 514 U.S. at 163-64 (explaining that trademark law "reduce[s] the customer's costs of shopping and making purchasing decisions," and "helps assure a producer that it (and not an imitating competitor) will reap the financial, reputation-related rewards associated with a desirable product" (internal quotation marks omitted) (alteration in original)); Union Nat'l Bank of Tex., Laredo v. Union Nat'l Bank of Tex., Austin, 909 F.2d 839, 844 (5th Cir. 1990) ("The idea is that trademarks are 'distinguishing' features which lower consumer search costs and encourage higher quality production by discouraging free-riders."). Cf. Mishawaka Rubber \& Woolen Mfg. Co. v. S.S. Kresge Co., 316 U.S. 203, 205 (1942) ("A trade-mark is a merchandising short-cut which induces a purchaser to select what he wants, or what he has been led to believe he wants.").

For other applications of the search costs theory of trademarks, see, e.g., Michael Grynberg, The Road Not Taken: Initial Interest Confusion, Consumer Search Costs, and the Challenge of the Internet, 28 Seattle U. L. Rev. 97 (2004). To be sure, there have been other explanations offered for trademark law. We analyze and critique several of them in Dogan \& Lemley, Search Costs, supra note *.

7. See Hal R. Varian, Microeconomic Analysis 82 (2d ed. 1984) (describing "perfect information" as one of the characteristics of a competitive market). To some extent, the brand-based product differentiation encouraged by trademark law arguably runs in tension with the law's information-facilitating goals. Ralph Brown famously argued that strong trademark protection has the effect of misallocating resources toward advertising, "[m]ost [of which], however, is designed not to inform, but to persuade and influence." Ralph S. Brown, Jr., Advertising and the Public Interest: Legal Protection of Trade Symbols, 57 Yale 
consumers can trust the accuracy of trademarks, and this is where the law comes in. ${ }^{8}$ By protecting established trademarks against confusing imitation, the law ensures a reliable vocabulary for communications between producers and consumers. Both sellers and buyers benefit from the ability to trust this vocabulary to mean what it says. Sellers benefit because they can invest in goodwill with the knowledge that others will not appropriate it. ${ }^{9}$ Consumers benefit because they do not have to do exhaustive research or even spend extra time looking at labels before making a purchase; they can know, based on a brand name, that a product has the features they are seeking. ${ }^{10}$ Trademark law, in other words, aims to promote rigorous, truthful competition in the marketplace by preserving the clarity of the language of trade. ${ }^{11}$

L.J. 1165, 1169 (1948) (footnote omitted). Furthermore, "[c]onsidering the economic welfare of the community as a whole, to use up part of the national product persuading people to buy product $A$ rather than product $B$ appears to be a waste of resources." Id. Yet trademarks undeniably provide value in conveying information about products and sources. Thus, "the only sensible conclusion, and the one eventually reached, was that trademark protection can both advance and disserve the development of an efficient and desirably competitive market." Glynn S. Lunney, Jr., Trademark Monopolies, 48 Emory L.J. 367, 370 (1999). The key was to craft rules that minimized trademarks' anticompetitive effects. Id. at 371.

The separate question of when and how consumers seek and process information is a complex one, drawing from neuroscience as well as marketing theory. For glimpses, see, e.g., Eric Goldman, Deregulating Relevancy in Internet Trademark Law, 54 Emory L.J. 507 (2005); Rebecca Tushnet, Gone in 60 Milliseconds: Trademark Law and Neuroscience (working paper 2007); Thomas Lee, Trademarks, Consumer Psychology, and the Sophisticated Consumer, available at http://papers.ssrn.com/sol3/papers.cfm?abstract_id= 967742 (working paper 2007).

8. See Landes \& Posner, supra note 1, at 270 ("If the law does not prevent it, free riding will eventually destroy the information capital embodied in a trademark, and the prospect of free riding may therefore eliminate the incentive to develop a valuable trademark in the first place.").

9. By preserving the integrity of brands and advertising, trademark protection has a corollary effect of creating incentives to maintain high quality products. See Robert G. Bone, Enforcement Costs and Trademark Puzzles, 90 Va. L. Rev. 2099, 2108 (2004) ("[I]f consumers lacked the ability to distinguish one brand from another, firms would have no reason to create brands with more costly but higher quality characteristics.").

10. See Smith v. Chanel, Inc., 402 F.2d 562, 566 (9th Cir. 1968) ("Preservation of the trademark as a means of identifying the trademark owner's products ... makes effective competition possible in a complex, impersonal marketplace by providing a means through which the consumer can identify products which please him and reward the producer with continued patronage. Without some such method of product identification, informed consumer choice, and hence meaningful competition in quality, could not exist.").

11. See Economides, Trademarks, supra note 6, at 602 (stating that trademarks "facilitate and enhance consumer decisions"); William P. Kratzke, Normative Economic Analysis of Trademark Law, 21 Memphis St. U. L. Rev. 199, 214-17 (1991) (arguing that trademarks are highly efficient means of conveying product information); Phillip Nelson, Advertising as Information, 82 J. Pol. Econ. 729, 729-31, 743-52 (1974) (arguing that the simple fact that a product is advertised conveys information about the "experience qualities" of that product); Phillip Nelson, Information and Consumer Behavior, 78 J. Pol. Econ. 311, 323-25 (1970) (comparing the advantages of national-brand versus retail advertising); 
While the reduction of consumer search costs and the encouragement of goodwill investment represent critical intermediate objectives of the trademark system, neither of these goals is an end in itself. The law reduces consumer search costs in order to facilitate the functioning of a competitive marketplace. Informed consumers will make better-informed purchases, which will increase their overall utility and push producers to develop better quality products. ${ }^{12}$ Trademark law, then, aims to promote more competitive markets by improving the quality of information in those markets. ${ }^{13}$

Trademark law therefore represents an affirmation of, rather than a departure from, the competitive model that drives the United States economy. It is in this respect distinct from the rest of intellectual property (IP) law, which departs from the competitive norm in order to encourage investment in invention and creation. ${ }^{14}$ Like antitrust laws, false advertising laws, and other consumer protection statutes, trademark law both draws from and reinforces the notion that competitive markets, under ordinary circumstances, will ensure efficient resource allocation and bring consumers the highest quality products at the lowest prices. ${ }^{15}$

\section{B. Some Limiting Rules of Trademark Law and Their Search Costs Rationale}

The pro-information, pro-competition goal of trademark law has several important implications for the scope of trademark protection, particularly in comparison to other areas of IP law. Overly restrictive trademark law has the potential to stifle competition rather than to facilitate it. Particularly when trademark holders have economic power, giving them absolute control over uses of their marks could erect significant barriers to

George J. Stigler, The Economics of Information, 69 J. Pol. Econ. 213, 220-24 (1961) (arguing that, although imperfect, advertising is a valuable means to reduce consumer ignorance).

12. Indeed, classical economics requires fully informed buyers and sellers as a condition for a perfectly competitive economy. See Maureen A. O'Rourke, Shaping Competition on the Internet: Who Owns Product and Pricing Information? 53 Vand. L. Rev. 1965, 1968 (2000) (describing conditions for perfectly competitive market).

13. Cf. Landscape Forms, Inc. v. Columbia Cascade Co., 113 F.3d 373, 379 (2d Cir. 1997) ("TT]he Lanham Act must be construed in light of a strong federal policy in favor of vigorously competitive markets, which is exemplified by the Sherman Act and other antitrust laws.").

14. See, e.g., Mark A. Lemley, The Economics of Improvement in Intellectual Property Law, 75 Tex. L. Rev. 989 (1997).

15. See generally Mark A. Lemley, Property, Intellectual Property, and Free Riding, 83 Tex. L. Rev. 1031 (2005). 
entry for competitors seeking to describe their own products. ${ }^{16}$ Even in less differentiated markets, strong trademark rights come at a cost because they have the potential to remove words from our language and product features from competition. ${ }^{17}$ One task of trademark law, then, is to preserve the informative role of trademarks while minimizing these downside risks. One way trademark law does this is by granting trademark owners rights that are less than absolute.

First and most generally, trademarks are not property rights in gross, but limited entitlements to protect against uses that diminish the informative value of marks. ${ }^{18}$ Trademark law historically limited itself to preventing uses of marks that "defraud[ed] the public"19 by confusing people into believing that an infringer's goods were produced or sponsored by the trademark holder. ${ }^{20}$ Likelihood of confusion does not necessarily follow every

16. See Lunney, supra note 7 , at 421 (noting that trademark protection may encourage monopolistic behavior).

17. See Rochelle Cooper Dreyfuss, Expressive Genericity: Trademarks as Language in the Pepsi Generation, 65 Notre Dame L. Rev. 397, 398-99 (1990) (noting that current jurisprudence deals poorly with the evolving significance of trademarks as a part of language).

18. See Beanstalk Group, Inc. v. AM Gen. Corp., 283 F.3d 856, 861 (7th Cir. 2002) (stating that "a trademark is an identifier, not a freestanding piece of intellectual property; hence the rule that a trademark cannot be sold in gross, that is, without the assets that create the product that it identifies"); Marshak v. Green, 746 F.2d 927, 929 (2d Cir. 1984) (invoking the rule against assignments of trademarks in gross, which states that "[a] trade name or mark is merely a symbol of goodwill; it has no independent significance apart from the goodwill it symbolizes"). See generally ETW Corp. v. Jireh Publ'g, Inc., 332 F.3d 915, 922 (6th Cir. 2003) (differentiating between trademarks and patents because the latter confer a property right in gross rather than a limited interest). Professor Landes and Judge Posner explain that the rule against the transfer of trademarks in gross is important to prevent consumer deception during a "last-period" game, in which the company is going out of business and wishes to spend its goodwill; the long-term effect of permitting confusion of consumers in this way would be to increase aggregate search costs. See Landes \& Posner, supra note 6, at 185-86; see also Kratzke, supra note 11, at 247-49 (offering an economic rationale for the rule "that a trademark user cannot assign the trademark in gross"); Stephen L. Carter, The Trouble With Trademark, 99 Yale L.J. 759, 786 (1990) (arguing that the prohibition on assignments in gross is consistent with trademark theory properly understood) [hereinafter Carter, Trouble With Trademark]. Cf. Lemley, Modern Lanham Act, supra note 6, at 1709-10 (criticizing trends in trademark law that permit transfers in gross). But see Allison Sell McDade, Note, Trading in Trademarks-Why the AntiAssignment in Gross Doctrine Should Be Abolished When Trademarks Are Used as Collateral, 77 Tex. L. Rev. 465 (1998) (proposing that in gross assignment rights be permitted when the assignment is offered as collateral for a loan).

19. Taylor v. Carpenter, 23 F. Cas. 742, 744 (C.C.D. Mass. 1844) (No. 13,784).

20. The most significant exception to this rule may be the merchandising cases, in which some courts have allowed trademark holders to prevent use of their marks as products, rather than as indicators of the brand or source of products. See, e.g., Boston Athletic Ass'n v. Sullivan, 867 F.2d 22, 35 (1st Cir. 1989) (finding infringement in unauthorized sale of "Boston Marathon" T-shirts, reasoning that "when a manufacturer intentionally uses another's mark as a means of establishing a link in consumers' minds with the other's enterprise, and directly profits from that link, there is an unmistakable 
time a party adopts another's trademark; it turns on a complex analysis that considers competitive proximity, consumer sophistication, and other factors that explore whether a use will truly create a false association in the minds of consumers, and thus taint the information marketplace. ${ }^{21}$ Although Congress recently added a federal cause of action based on the "dilution" of famous trademarks, ${ }^{22}$ the statute focuses on uses that increase consumer search costs, either by "blurring" the significance of a unique mark $^{23}$ or by giving such a mark a negative association, ${ }^{24}$ and to permit uses such as commentary and comparative advertising that actually facilitate consumer search. ${ }^{25}$ Like the

aura of deception"). The Fifth Circuit ushered in this trend in the Boston Hockey opinion, which found infringement in the absence of any confusion as to source or sponsorship:

The confusion or deceit requirement [of the Lanham Act] is met by the fact that the defendant duplicated the protected trademarks and sold them to the public knowing that the public would identify them as being the teams' trademarks. The certain knowledge of the buyer that the source and origin of the trademark symbols were in plaintiffs satisfies the requirement of the act.

Boston Prof'l Hockey Ass'n v. Dallas Cap \& Emblem Mfg., Inc., 510 F.2d 1004, 1012 (5th Cir. 1975) (emphasis added). But at least as many courts have rejected the merchandising theory, and it is likely the U.S. Supreme Court would do so as well. See Stacey L. Dogan \& Mark A. Lemley, The Merchandising Right: Fragile Theory or Fait Accompli? 54 Emory L.J. 461, 496-505 (2005) [hereinafter Dogan \& Lemley, Merchandising]; see also Lemley, Modern Lanham Act, supra note 6, at 1706-09 (criticizing the merchandising right cases).

21. See Polaroid Corp. v. Polarad Elecs. Corp., 287 F.2d 492, 495 (2d Cir. 1961) (establishing factors of likelihood of confusion between different products in the Second Circuit); see also AMF Inc. v. Sleekcraft Boats, 599 F.2d 341, 348 \& n.11, 349 (9th Cir. 1979) (identifying likelihood of confusion factors in the Ninth Circuit).

22. See Federal Trademark Dilution Act of 1995, 15 U.S.C. § 1125(c) (2000) (providing federal cause of action for trademark dilution). Congress revised the statute in 2006 to modify the standard for establishing dilution and to clarify the scope of dilution defenses. See Federal Trademark Dilution Revision Act of 2006, P.L. 109-312, 120 Stat. 1730.

23. 15 U.S.C. $§ 1125$ (c)(2)(B) (defining "dilution by blurring" as "association arising from the similarity between a mark or trade name and a famous mark that impairs the distinctiveness of the famous mark"). At least in the case of truly singular marks, such dilution by blurring can increase consumer search costs by making consumers look further for context, rather than immediately associating the trademark with its sole owner. See O'Rourke, Defining the Limits, supra note 2 at 291-95 \& n.65 (1997) (noting the harms of dilution). If consumers hear the term "Exxon," they think immediately of the oil company. If they hear "National" or "United," by contrast, they need context to understand what is being referred to. The risk of blurring is precisely that unique terms will over time be relegated to context-specific terms. Id.; Dogan \& Lemley, Merchandising, supra note 20, at 493-95 (explaining how dilution is consistent with the search costs rationale). One might reasonably question how much of an increase in search costs this represents, however. See Tushnet, supra note 7 (doing so).

24. 15 U.S.C. $§ 1125$ (c)(4) (defining dilution by tarnishment as "association arising from the similarity between a mark or trade name and a famous mark that harms the reputation of the famous mark").

25. 15 U.S.C. $\S 1125(\mathrm{c})(3)$ (exempting parody, comparative commercial advertising, noncommercial use, and news reporting from a claim of trademark dilution). The Supreme Court further limited the original dilution law by interpreting it to require actual injury to the source-identifying function of a famous trademark. See Moseley v. V Secret Catalogue, Inc., 
more traditional likelihood of confusion analysis, therefore, dilution - at least as properly understood ${ }^{26}$ — turns on injury to the informative value of a mark. ${ }^{27}$

Second, trademark law rewards-and provides incentives for-investment in goodwill, but does not provide rights to all of the economic value that derives from that goodwill. Our competitive economy is based on the premise that competitors can generally appropriate ideas for products and services, as long as they are doing so in a non-deceptive way and are not infringing some other exclusive right, such as copyright or patent. ${ }^{28}$ The

537 U.S. 418, 432-34 (2003) (holding that 15 U.S.C. $§ 1125(c)(1)$ "requires a showing of actual dilution, rather than a likelihood of dilution"). Whether requiring actual harm was in fact in the public interest is open to question, because the federal dilution statute generally limits remedies to prospective injunctive relief. See 15 U.S.C. § 1125(c)(2). And indeed Congress changed the standard to likelihood of confusion in its 2006 revisions. But the Court's instinct that the law must limit the scope of dilution is in some ways undoubtedly correct, and the 2006 revisions also made it more difficult to qualify for dilution protection and expanded the defenses for those whose use of a mark was actually reducing, rather than increasing, search costs.

26. Although courts seem to understand the concept of blurring the distinctiveness of a formerly unique mark, they occasionally have more difficulty with dilution by tarnishment. In theory, tarnishment applies only where the defendant brands its own goods with the plaintiff's mark, and where those goods are inferior in quality to or less reputable than the plaintiff's unrelated goods. See L.L. Bean, Inc. v. Drake Publishers, Inc., 811 F.2d 26, 31 (1st Cir. 1987) (noting that "[a] trademark is tarnished when consumer capacity to associate it with the appropriate products or services has been diminished [by being] linked to products which are of shoddy quality"). For example, if a defendant sells Toyota-brand pornography, those who encounter the use may think less highly of the Toyota brand name because they subconsciously associate it with pornography, even if they understand that the car company did not itself sponsor the materials.

Courts applying the tarnishment doctrine have sometimes used it to target criticism or derogatory speech about the trademark owner, a result that finds little justification in the search costs rationale. See, e.g., Deere \& Co. v. MTD Prods., Inc., 41 F.3d 39, 44-46 (2d Cir. 1994). Most courts, however, properly distinguish the two. See, e.g., Mattel, Inc. v. Walking Mountain Prods., 353 F.3d 792, 812 (9th Cir. 2003) (holding that noncommercial parody is protected by the First Amendment and not subject to trademark dilution claims); MasterCard Int'l, Inc. v. Nader 2000 Primary Comm., Inc., 70 U.S.P.Q.2d 1046, 1053-55 (S.D.N.Y. 2004) (determining that Nader's political advertisements in the 2000 presidential campaign were not commercial in nature and thus not actionable dilution).

27. See Moseley, 537 U.S. at 433-34 (stating that under the FTDA, mental association with another product does "not necessarily reduce the capacity of the famous mark to identify the goods of its owner"); see also Stacey L. Dogan, An Exclusive Right to Evoke, 44 B.C. L. Rev. 291, 315-16 (2003) (interpreting Moseley to limit the federal antidilution statute to uses that reduce the "singularity" of famous marks).

28. See TrafFix Devices, Inc. v. Mktg. Displays, Inc., 532 U.S. 23, 29 (2001) (“[C]opying is not always discouraged or disfavored by the laws which preserve our competitive economy.”); Deere \& Co. v. Farmhand, Inc., 560 F. Supp. 85, 98 (S.D. Iowa 1982) (“It is not only fair to imitate non-patented functional products, it is necessary to our form of economy."). When copying unprotected product features, competitors must sometimes take extra steps to protect against consumer confusion-for example, prominently using their own trademarks in marketing the copied product. See, e.g., Kellogg Co. v. Nat'l Biscuit Co., 305 U.S. 111, 120 (1938) ("Kellogg Company was free to use the pillow-shaped form, subject only to the obligation to identify its product lest it be mistaken for that of the plaintiff."); 
patent and copyright systems represent a response to the potential market failure that can result from the copying of public goods. ${ }^{29}$ By contrast, trademark law is avowedly not designed to resolve any perceived failure in the market for quality products and services, but instead failure in the market for information about those goods and services. ${ }^{30}$ Thus, trademark law is reluctant to provide protection for product configurations (where the shape is both the product and "information") because doing so may give the trademark owner control not just over search characteristics, but also over the intrinsic value of the product itself. ${ }^{31}$ Only where the product configuration has an established meaning as a brand in the minds of consumers is it entitled to protection. ${ }^{32}$ Even then, protection does not extend to "functional" features that would limit competition on the merits in a particular product market. ${ }^{33}$

The limitations considered in this section stem from the search-cost reducing goal of trademark law. When a word or product feature does not inform consumers about the product's source or sponsorship, legal protection for that word or feature would not reduce consumer search costs and is therefore denied. ${ }^{34}$

Fisher Stoves, Inc. v. All Nighter Stove Works, Inc., 626 F.2d 193, 195 (1st Cir. 1980) (determining that the defendant took the necessary precautions to avoid consumer confusion by clearly displaying its name and logo on the product). In this way, the courts protect the competitive marketplace while at the same time keeping search costs to a minimum. Cf. Sears, Roebuck \& Co. v. Stiffel Co., 376 U.S. 225 (1964). Although states "may, in appropriate circumstances, require that goods... be labeled or that other precautionary steps be taken to prevent customers from being misled as to the source," they "may not, when the article is unpatented and uncopyrighted, prohibit the copying of the article itself." Id. at 232-33.

29. In economic terms, a public good is both nonrivalrous and nonexcludable, meaning that after it has been created and released, many parties can possess it simultaneously and the original creator cannot physically exclude others from doing so. See Bruce Abramson, Promoting Innovation in the Software Industry: A First Principles Approach to Intellectual Property Reform, 8 B.U. J. Sci. \& Tech. L. 75, 92 (2002). U.S. copyright and patent law rest on the notion that, absent some form of legal protection, creators will under-invest in public goods such as useful inventions, art, and music. See, e.g., Wendy J. Gordon, Asymmetric Market Failure and Prisoner's Dilemma in Intellectual Property, 17 U. Dayton L. Rev. 853, 854-55 (1992); Wendy J. Gordon, Fair Use as Market Failure: A Structural and Economic Analysis of the Betamax Case and its Predecessors, 82 Colum. L. Rev. 1600, 1610-11 (1982).

30. See TrafFix Devices, 532 U.S. at 29 (noting that certain types of copying, such as reverse engineering, are fundamental to the workings of our competitive economy).

31. See Wal-Mart Stores, Inc. v. Samara Bros., 529 U.S. 205, 212-14 (2000) (pointing out that most design configurations reflect functional purposes rather than a means of identification for consumers).

32. Id. at 212 .

33. See, e.g., Traffix Devices, 532 U.S. at 29. But cf. Bone, supra note 9, at 2175-81 (noting that inquiry in functionality cases does not focus on the effect on competition in particular product markets, largely because of the difficulty of defining relevant markets).

34. For this reason, descriptive terms, like product configurations, merit protection only after they have acquired secondary meaning. See, e.g., Zatarain's, Inc. v. Oak Grove Smokehouse, Inc., 698 F.2d 786, 790 (5th Cir. 1983). 
Even when a mark is protected, the law quite reasonably permits uses of the mark that do not make a consumer's search more difficult, either by confusing the consumer or reducing the capacity of the mark to identify goods. Absent some legitimate reason to prevent such use, trademark law accepts the core premise that unfettered competition will generate the best results for consumers.

\section{SEARCH COSTS AND TRADEMARK LIMITING DOCTRINES}

The rule that trademark law is designed to reduce search costs justifies not just boundaries on the affirmative scope of trademark rights but doctrines that carve out limits from the ordinary scope of those rights. In the most straightforward of the trademark limiting doctrines, a party's truthful use of a mark unambiguously lowers search costs and thus deserves protection. Other doctrines, however, involve more uncertain informational effects. We consider both types of doctrines in this section.

\section{A. Limiting Doctrines That Unambiguously Lower Search Costs}

The first group of trademark doctrines is fairly straightforward. In these cases, the use the defendant makes of a mark is a truthful one that gives consumers valuable information, and so permitting the use is consistent with the goal of lowering consumer search costs.

\section{Comparative and Other Truthful Advertising}

One example is truthful advertising about the nature and source of the product. Resellers of new, used, and refurbished products have a right to use trademarks to accurately identify the original source of the goods. ${ }^{35}$ The fact that these parties advertise using the trademark is not illegal because they have legitimate reasons to attract the attention of those seeking the trademarked

35. See, e.g., Scott Fetzer Co. v. House of Vacuums Inc., 381 F.3d 477 (5th Cir. 2004) (permitting resale and repair shop to use the names of the brands it supplied); Nitro Leisure Prods., L.L.C. v. Acushnet Co., 341 F.3d 1356, 1364-65 (Fed. Cir. 2003) (permitting a refurbisher of used golf balls to sell them under their original brand name); Bijur Lubricating Corp. v. Devco Corp., 332 F. Supp. 2d 722, 730-31 (D.N.J. 2004) (permitting resellers of used and refurbished goods to sell their wares as used or refurbished under the original trademark); Bumble Bee Seafoods, L.L.C. v. UFS Indus., 71 U.S.P.Q.2d 1684 (S.D.N.Y. 2004) (permitting tuna-salad maker that used Bumble Bee tuna in its salad to advertise that fact). 
good. ${ }^{36}$ "The result is, of course, that the second-hand dealer gets some advantage from the trade mark. But ... that [rule] is wholly permissible so long as the manufacturer is not identified with the inferior qualities of the product resulting from wear and tear or the reconditioning by the dealer." 37

The right to engage in truthful advertising extends beyond the resale of the trademark owner's products. Competitors have an affirmative right to use others' trademarks to capture public attention and attempt to divert it to their own products by providing useful information that compares those products. As long as they do not mislead people into presuming some kind of affiliation between themselves and the trademark holder, competitors may use the mark to explain that their product imitates or aspires to the qualities of the trademark holder's goods.

In Saxlehner $v$. Wagner, ${ }^{38}$ for example, the Supreme Court allowed a natural water producer to use its competitor's mark to identify the product that it was copying. ${ }^{39}$ Justice Holmes explained that as long as the defendants did not create confusion about the real source of their product, they were free "to tell the public what they are doing and to get whatever share they can in the popularity of the [trademarked product] by advertising that they are trying to make the same article and think that they succeed." 40 The Court distinguished between deceptive appropriation of goodwill and legitimate comparative advertising, concluding that by flagging its product as an imitator of the original, "they are not trying to get the good will of the name, but the good will of the goods." 41

Similarly, in Smith $v$. Chanel, Inc. ${ }^{42}$ the court allowed a knock-off perfume manufacturer to advertise that its perfume smelled like Chanel No. 5.43 The court dismissed Chanel's

36. Scott Fetzer Co., 381 F.3d at 439 ("Independent dealers and repair shops may use a mark to advertise truthfully that they sell or repair certain branded products ...."); Bijur Lubricating Corp., 332 F. Supp. at 731 (permitting the use of the trademark in metatags).

37. Champion Spark Plug Co. v. Sanders, 331 U.S. 125, 130 (1947). In cases involving used or reconditioned products, courts require disclosure of that fact rather than preventing the seller from using the manufacturer's trademark. Id.; $c f$. Rolex Watch, U.S.A., Inc. v. Michel Co., 179 F.3d 704, 709-10 (9th Cir. 1999) (refusing to allow reseller to use Rolex mark when modifications to watches were so substantial that they "result[ed] in a new product”).

38. 216 U.S. 375 (1910).

39. Id. at $379-80$.

40. Id. at 380 .

41. Id. at $380-81$.

42. 402 F.2d 562 (9th Cir. 1968).

43. The defendant's advertisements included at least two references to Chanel No. 5. In one reference, the defendant challenged consumers: "We dare you to try to detect any difference between Chanel \#5 (25.00) and Ta'Ron's 2nd Chance. \$7.00.” Id. at 563. The 
argument "that protection should also be extended to the trademark's commercially more important function of embodying consumer good will created through extensive, skillful, and costly advertising," reasoning that "[t]he courts... have generally confined legal protection to the trademark's source identification function for reasons grounded in the public policy favoring a free, competitive economy." ${ }^{44}$ Landes and Posner explain that the result in Chanel is entirely consistent with the search costs rationale: "It would have been very costly for consumers to acquire such information [about the smell of the original perfume and the copy] before purchasing the copier's perfume because the perfume was sold through the mail." 45 But the search costs justification for comparative advertising is even stronger than they suggest. Truthful information about the similarities between two products lowers consumer search costs even if other ways of providing that information are not particularly costly. Trademarks work as signifiers precisely because they are a particularly efficient means of conveying information. They are useful in making comparisons for the same reason.

The same rationale has led courts to allow generic manufacturers to imitate branded trade dress in a way that evokes but does not confuse. ${ }^{46}$ These cases, like those involving comparative advertising, emphasize that the public benefits from having fuller information about the products available in the marketplace. ${ }^{47}$ The connection to search costs may be less obvious

corresponding order form listed "Second Chance" with "*(Chanel \#5)" just below it. Id. Accord Calvin Klein Cosmetics Corp. v. Lenox Labs., Inc., 815 F.2d 500, 503-04 (8th Cir. 1987) (upholding competitor's use of the Calvin Klein mark OBSESSION if used in a nondeceptive, comparative manner); G.D. Searle \& Co. v. Hudson Pharm. Corp., 715 F.2d 837, 842 \& n.12 (3d Cir. 1983) (generic could advertise that its product was "[e]quivalent to" plaintiff's if accompanied by a disclaimer); Upjohn Co. v. Am. Home Prods. Corp., 598 F. Supp. 550, 561 (S.D.N.Y. 1984) (permitting maker of Advil to advertise Advil's equivalent strength to Motrin by using the Motrin mark).

44. Chanel, 402 F.2d at 566.

45. Landes \& Posner, supra note 6, at 206.

46. See Am. Home Prods. Corp. v. Barr Labs., Inc., 656 F. Supp. 1058, 1068 (D.N.J. 1987) (construing New Jersey and federal trademark statutes to render unlicensed imitation "irrelevant unless confusion also is shown"); see also Conopco, Inc. v. May Dep't Stores Co., 46 F.3d 1556, 1565 (Fed. Cir. 1994) (finding no infringement when private label retailer "packages its product in a manner to make it clear to the consumer that the product is similar to the national brand, and is intended for the same purposes").

47. Am. Home Prods., 656 F. Supp. at 1068.

The resemblance between two products can alert consumers to the functional or utilitarian equivalence between them, to the fact that one product may be substituted for the other in the ultimate uses for which the products are intended. The free flow of information regarding the substitutability of products is valuable to individual consumers and to society collectively, and by providing it a supplier engages in fair competition based on those aspects-for example, price-in which the products differ. 
than in the comparative advertising case, but it is just as compelling: by providing consumers with visual indicators of a relationship between the product in question and branded products with which they have experience, the practice gives them a quick and easy way to comparison shop. Certainly, imitating the color of a box or the shape of a package operates at the level of subconscious attention-gathering rather than conscious comparison. But consumer search is by no means a process that always involves a conscious consideration of clearly identified criteria; it often turns on more subconscious judgments based on experience with particular products or brands. ${ }^{48}$ Making it easier for consumers to find like products will thus sometimes mean permitting manufacturers to make them look alike as well as describing their similarities, for example by using gold coloration on cola cans to indicate that the cola is caffeine-free. 49

Finally, competitors may use descriptive marks in their nontrademark sense to describe the features or qualities of their own products. ${ }^{50}$ "In essence, [this] fair use defense prevents a

Id. Not all countries protect comparative advertising to the same degree as the United States. See, e.g., Warren S. Grimes, Control of Advertising in the United States and Germany: Volkswagen Has a Better Idea, 84 Harv. L. Rev. 1769, 1787 (1971) (discussing limitations on comparative advertising in Germany). But with the passage of the Comparative Advertising Directive, Directive 97/55/EC (Oct. 6, 1997), law in the EU began to improve.

48. For discussion of the extensive literature on this point in cognitive psychology, see, e.g., Goldman, supra note 7; Barton Beebe, The Semiotic Analysis of Trademark Law, 51 UCLA L. Rev. 621 (2004); Rebecca Tushnet, Gone in 60 Milliseconds: Trademark Law and Neuroscience (working paper 2006). Indeed, one author has gone so far as to argue that trademark law as a whole should be understood as "designed to accommodate and even harness non-rational human thought processes, rather than suppress or eradicate them." Jeremy N. Sheff, The (Boundedly) Rational Basis of Trademark Liability: Reconciling the Federal Trademark Dilution Act and the Lanham Act, 15 Tex. Intell. Prop. L.J. 331, 334 (2007). To be sure, this fact is sometimes used as an argument in favor of stronger trademark protection by those who contend that a mere mental association between two products will either confuse consumers or dilute the strength of a trademark. See, e.g., Jacob Jacoby, The Psychological Foundations of Trademark Law: Secondary Meaning, Genericism, Fame, Confusion, and Dilution, 91 TMR 1013 (2001); Jerre B. Swann \& Theodore H. Davis, Jr., Dilution, An Idea Whose Time Has Gone; Brand Equity As Protectable Property, The New/Old Paradigm, 84 TMR 267 (1994). But as long as consumers are capable of distinguishing between the two products, there is no reason to believe that the evocation will have any negative effect on the strength or quality of the original brand. Indeed, the fact that one product references the other may strengthen the brand association in the minds of consumers. See Chi-Ru Jou, The Perils of a Mental Association Standard of Liability: The Case Against the Subliminal Confusion Cause of Action, 11 Va. J. L. \& Tech. 2, ๆ58-60 (2006).

49. We are indebted to Ariel Katz for this example.

50. See 15 U.S.C. $§ 1115(b)(4)$ (2000) (providing a defense to infringement when a term is used "fairly and in good faith ... to describe the goods or services of [the] party"); Zatarain's, Inc., 698 F.2d at 791 (describing the "fair-use" defense); see also Car-Freshner Corp. v. S.C. Johnson \& Son, Inc., 70 F.3d 267, 269 (2d Cir. 1995) ("[I]t should make no difference whether the plaintiff's mark is to be classed on the descriptive tier of the 
trademark registrant from appropriating a descriptive term for its own use to the exclusion of others, who may be prevented thereby from describing their own goods." 51 Again, the interest protected is informational: trademark holders may not interfere with the ability of others to describe their products in truthful, nondeceptive ways.

\section{Trademark Use ${ }^{52}$}

The trademark use doctrine attempts to ensure that the trademark grant does not stifle informative speech by noncompetitors. To infringe a trademark, a defendant must "use[]" a mark "in commerce" "on or in connection with any goods or services." 53 Courts historically insisted that trademark "use" required that the defendant market goods or services under the mark. ${ }^{54}$ As the Eighth Circuit recently explained, "the mark holder is generally not entitled to relief unless the defendant advertises or otherwise promotes [the actual mark] thereby causing the public to see the protected mark and associate the infringer's goods or services with those of the mark holder." 55 Defendants who do not

trademark ladder.... What matters is whether the defendant is using the protected word or image descriptively, and not as a mark.").

51. Zatarain's, 698 F.2d at 791.

52. For reasons we have explained elsewhere, we believe trademark use is an affirmative part of a plaintiff's trademark case, not a defense. See, e.g., Stacey L. Dogan \& Mark A. Lemley, Grounding Trademark Law Through Trademark Use, 92 Iowa L. Rev. 1669 (2007) [hereinafter Dogan \& Lemley, Grounding]. Our discussion here is a necessarily truncated one; for a fuller justification for the doctrine, see that article.

53. 15 U.S.C. $\S 1125(\mathrm{a})(1)$ (2000); see also id. $\S 1114(\mathrm{a})(1)$. The act defines "use in commerce" as "the bona fide use of a mark in the ordinary course of trade, and not made merely to reserve a right in a mark." 15 U.S.C. $§ 1127$. A use qualifies as a use in commerce on goods only when

(A) it is placed in any manner on the goods or their containers or the displays associated therewith or on the tags or labels affixed thereto, or if the nature of the goods makes such placement impracticable, then on documents associated with the goods or their sale, and

(B) the goods are sold or transported in commerce.

Id. For services, a use qualifies "when it is used or displayed in the sale or advertising of services and the services are rendered in commerce." $I d$.

54. See Felix the Cat Prods. v. New Line Cinema Corp., 54 U.S.P.Q.2d 1856, 1858 (C.D. Cal. 2000) ("Use of the character as an expression of an idea or device to 'set the mood' of the Picture does not qualify as use of the mark 'to identify or distinguish' goods 'to indicate their source' as required to fall under the purview of trademark law."). As we explain elsewhere, the issue rarely arose until recently because trademark owners did not even try to claim ownership over the sorts of uses they now seek to prevent. See Dogan \& Lemley, Grounding, supra note 52.

55. DaimlerChrysler AG v. Bloom, 315 F.3d 932, 939 (8th Cir. 2003) (emphasis added). Many courts adopting the trademark use doctrine have relied upon the "in connection with" language in the Lanham Act. See, e.g., Bosley Med. Inst., Inc. v. Kremer, 403 F.3d 672, 67980 (9th Cir. 2005) (finding the appropriate inquiry in evaluating the "in connection with" 
themselves "use" a mark in commerce can face liability for another's infringement only if they actively induce that infringement or knowingly help to bring it about. 56

The trademark use doctrine is under attack in the Internet context, ${ }^{57}$ and we have elsewhere offered a detailed defense of the

requirement, as "whether [defendant] offers competing services to the public"); Holiday Inns, Inc. v. 800 Reservation, Inc., 86 F.3d 619, 623-26 (6th Cir. 1996) (holding that the use of a telephone number that translated into 1-800-H0LIDAY-with a zero in place of the "O"-was not trademark "use" within the Lanham Act because the defendant had not advertised its services under the offending alphabetical translation). Others have relied on the "use in commerce" language. See, e.g., 1-800 Contacts, Inc. v. WhenU.com, Inc., 414 F.3d 400, 407-11 (2d Cir. 2005) (relying on the "use in commerce" requirement to find no direct infringement by a party selling pop-up advertisements); Karl Storz Endoscopy-Am., Inc. v. Surgical Techs., Inc., 285 F.3d 848, 855 (9th Cir. 2002) (“'[U]se in commerce' appears to contemplate a trading upon the goodwill of or association with the trademark holder."); Site Pro-1, Inc. v. Better Metal, LLC, No. CV-06-6508, 2007 WL 1385730, at *4 (E.D.N.Y. May 9, 2007); Best Western Int'l, Inc. v. Doe, No. CV-06-1537-PHX-DGC, 2006 WL 2091695, at *5 (D. Ariz. July 25, 2006); cf. Hamzik v. Zale Corp., No. 3:06-cv-1300, 2007 WL 1174863, at *3 (N.D.N.Y. April 19, 2007) (finding potential trademark use by a keyword advertiser that displayed plaintiff's trademark in the text of its ad). Still others have held that the trademark use doctrine bars claims without specific reference to statutory language. See, e.g., Universal Comm. Sys., Inc. v. Lycos, Inc., 478 F.3d 413, 424 (1st Cir. 2007) (rejecting a state dilution claim because "Lycos might profit by encouraging others to talk about UCS under the UCSY name, but neither that speech nor Lycos's providing a forum for that speech is the type of use that is subject to trademark liability"); Nautilus Group, Inc. v. Icon Health \& Fitness, Inc., No. CO2-242ORSM, 2006 WL 3761367, at *5 (W.D. Wash. Dec. 21, 2006) (holding that an advertiser's use of a keyword to generate a sponsored link to run a comparative advertisement was not a trademark use for dilution purposes); Merck \& Co., Inc. v. Mediplan Health Consulting, Inc., 431 F. Supp. 2d 425, 428 (S.D.N.Y. 2006); Rescuecom Corp. v. Google, Inc., 456 F. Supp. 2d 393, 398-403 (N.D.N.Y. 2006) (finding that sale of keyword-based advertising does not constitute "trademark use"); Lucasfilm Ltd. v. High Frontier, 622 F. Supp. 931, 934-35 (D.D.C. 1985).

56. See Inwood Labs., Inc. v. Ives Labs., Inc., 456 U.S. 844, 853-54 (1982) (concluding that manufacturers and distributors are liable for harm resulting from their intentional inducement of another to engage in trademark infringement).

57. See, e.g., Playboy Enters., Inc. v. Netscape Communications Corp., 354 F.3d 1020 (9th Cir. 2004) (holding that search engine could face liability as direct infringer for selling keyword-based advertisements); Government Employees Insurance Co. v. Google Inc., No. 1:04CV507LMBTCB, 2004 WL 1977700 (E.D. Va. Aug. 25, 2004) (same); Google, Inc. v. Am. Blind \& Wallpaper, No. C-03-5340JF (RS), 2007 WL 1159950, at *6 (N.D. Cal. Apr. 18, 2007) (holding that a search engine's sale of keyword-based advertising can constitute trademark use under the Lanham Act); 800-JR Cigar, Inc. v. GoTo.com, Inc., 437 F. Supp. 2d 273, 282-93 (D.N.J. 2006) (allowing trademark claims against a pay-for-priority search engine based on its "sale" of keywords in exchange for prominent placement in search results); Merck \& Co., Inc. v. Mediplan Health Consulting, Inc., 431 F. Supp. 2d 425, 426-28 (S.D.N.Y. 2006) (rejecting a trademark claim based on keyword-based advertising because defendant did not make trademark use); Rescuecom Corp. v. Google, Inc., 456 F. Supp. 2d 393, 397-404 (N.D.N.Y. 2006) (same); Edina Realty, Inc. v. TheMLSonline.com, No. Civ. 044371JRTFLN, 2006 WL 737064, at *1-2 (D. Minn. Mar. 20, 2006) (allowing a trademark claim based on keyword-based advertising); Buying for the Home, LLC v. Humble Abode, LLC, 459 F. Supp. 2d 310, 321-24 (D.N.J. 2006) (same); Int'l Profit Assocs., Inc. v. Paisola, 461 F. Supp. 2d 672, 676-80 (N.D. Ill. 2006) (enjoining keyword advertising by a gripe site); cf. 1-800 Contacts, Inc. v. WhenU.com, Inc., 414 F.3d 400, 408-12 (2d Cir. 2005) (rejecting infringement claim based on pop-up advertisements); Google v. American Blind \& Wallpaper Factory, 74 U.S.P.Q.2d 1385 (N.D. Cal. 2005) (denying a motion to dismiss a 
doctrine. ${ }^{58}$ For now, suffice it to say that limiting trademark rights to a right to prevent confusing uses of the mark as a brand helps to ensure that trademark rights remain tied to their search costs rationale-only those individuals or companies who are using the mark to advertise their own products or services have the motive and opportunity to interfere with the clarity of the mark's meaning in conveying product information to consumers, and so only those uses ought to be of concern to trademark law. ${ }^{59}$ And by limiting trademark claims to those who themselves use marks in a way that suggests some affiliation between themselves and the trademark holder (and to others intimately involved in their infringing activities), the law ensures that information facilitators, publishers, and others who bear only a tangential relationship to trademark infringement can go about their business without the responsibility of having to police all of the parties with whom they have commercial relations.

keyword advertising complaint based on trademark use). Cf. 1-800 Contacts, Inc. v. WhenU.com, Inc., 414 F.3d 400 (2d Cir. 2005) (finding that "use" of trademark to generate pop-up ads did not constitute trademark use and could not be basis for direct infringement claim); Wells Fargo \& Co. v. WhenU.com, Inc., 293 F. Supp. 2d 734 (E.D. Mich. 2003) (same); U-Haul International, Inc. v. WhenU.com, Inc., 279 F. Supp. 2d 723 (E.D. Va. 2003) (same).

58. Dogan \& Lemley, Search Costs, supra note *; Dogan \& Lemley, Grounding, supra note 52 .

59. The Federal Trademark Dilution Act until 2006 required a "commercial use in commerce of a mark or trade name," 15 U.S.C. $§ 1125(c)(1)$ (2005), a standard that more explicitly incorporated the use requirement by applying only to "commercial speech" as that term is defined in First Amendment jurisprudence-speech that proposes a commercial transaction. H.R. Rep. No. 104-374, at 4 (1995), reprinted in 1995 U.S.C.C.A.N. 1029, 1031; see also Mattel, Inc. v. MCA Records, Inc., 296 F.3d 894, 905-06 (9th Cir. 2002), cert. denied, 537 U.S. 1171 (2003) (explaining that "noncommercial use" under the Federal Trademark Dilution Act "refers to a use that consists entirely of noncommercial, or fully constitutionally protected, speech"). While the inartful phrase "commercial use in commerce" was removed from the statute in the 2006 revision, the current language of the statute makes it clear that the defendant must use the plaintiff's term as a mark in order to be liable for dilution. It speaks expressly of the effect of the defendant's "mark or trade name," one that exists separately from the plaintiff's "famous mark." 15 U.S.C. § 1125(c)(1) (2006).

The trademark use doctrine is even more important in dilution than in ordinary trademark infringement, because trademarks are often what Barton Beebe calls "floating signifiers" that can have multiple meanings, not all of which the trademark owner is entitled to control. Beebe, supra note 48, at 667-69. The Visa credit card network may have a famous mark entitled to dilution protection, for instance, but that does not give them the right to prevent uses of the English word "visa" in connection with travel services companies. The trademark use doctrine helps prevent dilution from swallowing language in cases such as these. For a discussion of how, see Stacey L. Dogan \& Mark A. Lemley, The Trademark Use Requirement in Dilution Cases, Santa Clara Comp. \& High Tech. L.J. __ (forthcoming 2008). 


\section{Prohibitions on Naked Licensing and Assignments in Gross ${ }^{60}$}

Unlike copyrights and patents, which have the alienability attributes of real property, 61 trademarks have never been freely alienable.62 Indeed, selling a trademark without the accompanying business assets or goodwill is called "assignment in gross," and it can lead to the invalidation of the trademark.63 Unsupervised licensing of a trademark can invalidate it as well.64 The rationale for preventing free alienation of trademarks is closely tied to the search costs theory of trademarks.65 It is hard to see how the goals of preventing consumer confusion and encouraging investments in product quality would be furthered by allowing a company to sell the rights to a mark to another who will not make the same products at all or who will make products of different quality. If anything, assignments in gross are vehicles for adding to consumer confusion, not reducing it.66

Landes and Posner point out that trademark owners will frequently have an incentive to maintain the quality of goods they sell even after a transfer of trademark rights in gross. Only in "final period" cases, where a company might want to spend down

60. Portions of this section are adapted from Lemley, Modern Lanham Act, supra note 6 .

61. See 17 U.S.C. $§ 201(d)(e)(1994) ; 35$ U.S.C. $§ 261$ (2000).

62. See Kenneth L. Port, The Illegitimacy of Trademark Incontestability, 26 Ind. L. Rev. 519, 553 (1993) ("Trademarks, on the other hand, enjoy none of the 'bundle of rights' that other forms of property enjoy. ... Mark holders do not possess a property right in the mark itself, because trademarks are nothing when devoid of the goodwill they have come to represent or the product on which they are used.").

63. The Lanham Act provides that the trademark owner can assign the mark along with the accompanying goodwill. See 15 U.S.C. $\S 1060$ (1994). The negative implication is that it cannot be assigned otherwise. See Pepsico v. Grapette Co., 416 F.2d 285, 289-90 (8th Cir. 1969) (invalidating a trademark assigned in gross). For a discussion of the rule against assignment in gross, see $2 \mathrm{~J}$. Thomas McCarthy, Trademark and Unfair Competition $\S 18.01$, at $18-4$ to $18-16$. For criticism of the rule, see, e.g., Irene Calboli, Trademark Assignment "with Goodwill": A Concept Whose Time Has Gone, 57 Fla L. Rev. 771 (2005); McDade, supra note 18.

For an interesting example of assignments in gross, see Lisa Lerer, Bringing Back the Dead, Intell. Prop. L. \& Bus., June 2006, at 28 (discussing RiverWest Brands, which buys defunct brand names and markets products under those marks).

64. See, e.g., Stanfield v. Osborne Indus., 52 F.3d 867, 871-72 (10th Cir. 1995); Dawn Donut Co. v. Hart's Food Stores, 267 F.2d 358, 366 (2d Cir. 1959).

65. Indeed, the Supreme Court in American Steel Foundries v. Robertson, 269 U.S. 372 (1926), expressly traced the reasons for the rule to the fact that trademarks were only symbols of goodwill, rather than property in and of themselves. Id. at 380.

66. See, e.g., Carter, Trouble with Trademark, supra note 18, at 786 ("The deterioration of the prohibition on transfers in gross is a reflection of the continuing judicial misunderstanding of the theoretical underpinnings of trademark law. As a matter of theory, the prohibition on transfers in gross should be a firm one."); Kratzke, supra note 11, at 24749 (offering an economic rationale for the rule against assignments in gross). 
its stock of goodwill, will a transfer pose risks that a buyer will deliberately sell shoddy goods. ${ }^{67}$ Whether or not a transfer is part of a final period game, however, the mental association a consumer has between a trademark and a particular product will generally be weakened by assignments in gross, and search costs will accordingly go up. Indeed, Landes and Posner themselves note that an assignment in gross itself makes economic sense primarily when it will involve confusing a significant number of consumers. ${ }^{68}$

The law does not prevent all deceptions of consumers by the mark owner during such a last period problem. If Coca-Cola wanted to spend down its goodwill by cheapening Coke, it could do so, and people would buy the product for a little while. But the fact that the law doesn't prohibit all possible ways a trademark owner might deceive its own consumers for profit doesn't mean that it must permit transactions that seem primarily designed to do so. Not only are assignments in gross unsupported by the traditional economic rationale for trademarks, but they do active damage to the goals of trademark law. The mental associations consumers make between trademarks and products are weakened by such transfers. 69

The rule against naked licenses and assignments does create a problem for search-costs theory, however, because the remedy for such assignments-invalidation of the trademark, so that anyone is free to use it-is hardly likely to avoid confusing consumers of that product. This is an area in which the law has taken a longterm rather than a short-term view, concluding that invalidating trademarks that are assigned in gross will discourage such assignments, and therefore will reduce consumer confusion on average, even though the remedy doesn't eliminate confusion in the particular case before it.

\section{B. Doctrines With Ambiguous Search-Cost Effects}

The doctrines discussed in the previous section further the search costs rationale of trademark law in a straightforward waythey permit third parties to give consumers accurate information about products or the cultural significance of brand names. But trademark law's procompetitive objectives sometimes require more. In the doctrines considered in this section, the law limits a

67. Landes \& Posner, supra note 1, at 274-75.

68. See id. at 285 .

69. There is a positive economic case to be made for free alienability in general. Restraints on alienation generally interfere with the operation of the market and may prevent assets from being put to their highest and best use. While this is a powerful argument when applied to most assets, it is weaker when applied to trademarks, since the asset is defined by-indeed, consists of - the connection between goods and their particular manufacturer. 
trademark holder's rights even when competitors might appear to receive a windfall or some consumers may be confused as a result. The law does this for one of two reasons-either because overall search costs would be higher without the limitation on trademark rights, or because recognizing trademark rights would impede the ability of competitors to enter markets and compete. In either case, however, at least some consumers will suffer higher search costs as a result of the limitation. The genericness, functionality, and abandonment doctrines present "hard cases" precisely because there are search cost rationales on both sides of the argument.

For the most part, the courts have resolved these hard cases in favor of the defendant, withdrawing trademark protection entirely in cases in which doing so facilitates search for the majority of consumers, or where it ensures competitive access to particular product markets. In other words, when market access and competition run in tension with the trademark holder's interests in protecting its product-associated goodwill, the competitive interests generally trump. ${ }^{70}$

From a search costs perspective, the automatic preference given to one group of consumers over another can be troubling. True, there will be times when the law must choose a rule that will disadvantage some consumers in order to protect others, and if there really is no alternative, courts must choose the rule that most benefits consumers the most. But the law's preference for allor-nothing rules is a poor fit for these hard cases, and the courts can and should apply some of these limiting doctrines with greater nuance.

Several venerable doctrines of trademark law fall into this ambiguous-case category. We consider three such doctrines, and how the law might be modified to minimize consumer harm in each case.

\section{Genericide}

The genericness doctrine prevents a party from claiming rights to a term "that refers, or has come to be understood as referring, to the genus of which the particular product is a

70. See Kellogg Co., 305 U.S. at 122:

Kellogg Company is undoubtedly sharing in the goodwill of the article known as "Shredded Wheat"; and thus is sharing in a market which was created by the skill and judgment of plaintiff's predecessor and has been widely extended by vast expenditures in advertising persistently made. But that is not unfair. Sharing in the goodwill of an article unprotected by patent or trade-mark is the exercise of a right possessed by all-and in the free exercise of which the consuming public is deeply interested. 
species."71 Genericness arises in two different situations. Some terms are born generic, and the law refuses ever to grant them protection. No one is free to claim the term "Computer" as their exclusive trademark for computers, preventing competitors from using the normal term by which the public refers to the entire class of goods. ${ }^{72}$ Other terms are legitimate trademarks for many years, but come over time to be associated in the minds of the public not just with the trademark owner or its products but with the entire class of goods itself. When that happens, the law withdraws the protection it once granted. "Aspirin," "thermos," and "escalator" are all terms that were once trademarks but suffered this "genericide." 73 When a term has come to signify a class of goods, competitors have the right to explain what they are selling, even when their use of the generic term clearly piggybacks on the efforts of the party that first introduced the product. ${ }^{74}$

The genericness doctrine arises out of a concern for consumer search costs: Consumers will be misled if what they believe is a generic term is in fact a product sold by only one company. ${ }^{75}$ And if competitors cannot use the generic term to describe their own products, consumers will incur unnecessary expense in trying to locate the competitors' versions. At the same time, the genericide branch of the genericness doctrine can impose substantial search costs on consumers, particularly when a once-famous mark such as "aspirin" or "thermos" becomes generic. ${ }^{76}$ Consumers who associate

71. Abercrombie \& Fitch Co. v. Hunting World, Inc., 537 F.2d 4, 9 (2d Cir. 1976).

72. 2 McCarthy, supra note 60, § 12:1; see Gruner + Jahr USA Publ'g. v. Meredith Corp., 991 F.2d 1072, 1078 (2d Cir. 1993) (holding that PARENTS magazine could not prevent use of the name PARENTS' DIGEST because "registering the proper noun 'Parents' as a trademark scarcely can be held to have removed it from being available for use by others, or grant exclusive possession of this property right to the trademark registrant" (internal citation omitted)); see also J. Kohnstam, Ltd. v. Louis Marx \& Co., 280 F.2d 437, 440 (C.C.P.A. 1960) (denying the exclusivity of the word "matchbox" as used to describe a type of toy).

73. See 2 McCarthy, supra note $60, \S 12: 1$; cf. Union National Bank of Tex., Laredo, Tex., v. Union National Bank of Tex., Austin, Tex., 909 F.2d 839, 844 (5th Cir. 1990) ("The English language, more than most, is in a constant state of flux. A word which is today fanciful may tomorrow become descriptive or generic.").

74. See, e.g., Kellogg Co., 305 U.S. at 122; cf. Abercrombie \& Fitch, 537 F.2d at 9 ("[N]o matter how much money and effort the user of a generic term has poured into promoting the sale of its merchandise and what success it has achieved in securing public identification, it cannot deprive competing manufacturers of the product of the right to call an article by its name.").

75. See Bayer Co. v. United Drug Co., 272 F. 505, 509, 510-11 (S.D.N.Y. 1921) (analyzing whether aspirin had become a generic term to consumers); Landes \& Posner, supra note 1, at 296; Ralph H. Folsom \& Larry L. Teply, Trademarked Generic Words, 89 Yale L.J. 1323, 1337, 1342-43 (1980) (suggesting that hybrid terms would raise consumer search costs if they were granted continuing protections despite becoming generic).

76. See Bayer Co., 272 F. at 514-15; Am. Thermos Prods., Inc. v. Aladdin Indus., Inc., 207 F. Supp. 9, 14 (D. Conn. 1962). 
the famous mark with the company that uses it may well be confused when competitors begin using the mark as a generic term. ${ }^{77}$

The law is willing to make that sacrifice if enough consumers treat the term as generic, because the harm to consumers who associate the term with the entire class of goods outweighs the harm to the diminishing number who view it only as a mark. ${ }^{78}$ But because there are consumers on both sides who may be confused, the law has traditionally required significantly more evidence of genericide than it does for consumer confusion. While courts will enjoin a defendant's use of a mark on a showing of as little as $10 \%$ consumer confusion, ${ }^{79}$ they will not declare an existing mark generic unless a "substantial majority of the public" believes it describes a class of goods rather than a species within that class. ${ }^{80}$

Even with this accommodation to the interests of those who have come to understand the term as a mark, the all-or-nothing nature of the genericide determination is somewhat troubling from a search costs perspective. Consumers do not simply flip a switch in their minds and go from thinking of a term as signifying a product to thinking of it as signifying a class of products. Some may strongly hold one view or the other, but others may occupy a middle state, in which a term like "Kleenex" can signify a trademark in certain contexts at the same time that it is used in

77. For discussion of the loss of producer goodwill when a mark is declared generic, see Stephen L. Carter, Does It Matter Whether Intellectual Property Is Property? 68 Chi.-Kent L. Rev. 715, 722 (1993). On the interrelationship between genericide and patent protection, see Kellogg Co., 305 U.S. at 116-18 (noting that because the term "shredded wheat" is generic, "the original maker of the product acquired no exclusive right to use it"); $c f$. Gideon Parchomovsky \& Peter Siegelman, Towards an Integrated Theory of Intellectual Property, 88 Va. L. Rev. 1455, 1461 (2002) (commenting on the brand loyalty that remained with Bayer decades after "aspirin" became generic).

78. See Folsom \& Teply, supra note 75, at 1340-41; Landes \& Posner, supra note 1 , at 291-92; see also Justin Hughes, The Philosophy of Intellectual Property, 77 Geo. L.J. 287, 315-23 (1988) (noting that generic terms are "extraordinary ideas" that should remain open for all to use).

79. See Henri's Food Prods., Co. v. Kraft, Inc., 717 F.2d 352, 358 (7th Cir. 1983) (holding that $7.6 \%$ confusion was insufficient to establish likelihood of confusion, but collecting authorities finding likelihood confusion based on surveys showing as low as $8.5 \%$ confusion among consumers); Grotrian, Helfferich, Schulz, Th. Steinweg Nachf. v. Steinway \& Sons, 365 F. Supp. 707, 716 (S.D.N.Y. 1973), mod. on other grounds, 523 F.2d 1331 (2d Cir. 1975) (" $7.7 \%$. . . perceived a business connection between the two companies and $8.5 \%$ confused the names"); Jockey International, Inc. v. Burkard, 185 U.S.P.Q. 201, 205 (S.D. Cal. 1975) (stating that the survey showed that " 11.4 percent of the universe ... would associate defendants' JOCK SOCK underwear package with plaintiff'); Exxon Corp. v. Texas Motor Exchange of Houston, 528 F.2d 500, 507, 208, U.S.P.Q. 384, 390 (5th Cir. 1980) (stating that $15 \%$ was sufficient).

80. Murphy Door Bed Co. v. Interior Sleep Sys., Inc., 874 F.2d 95 (2d Cir. 1989); KingSeeley Thermos Co. v. Aladdin Indus., 321 F.2d 577, 579 (2d Cir. 1963). 
casual conversation in a generic way. ${ }^{81} \mathrm{~A}$ legal determination of genericide is an instantaneous elimination of the associations between mark and product built up in the minds of consumers. As such, it cannot help but confuse some-even some who also use the term in a generic sense in some contexts. ${ }^{82}$

We think that a legal doctrine designed to minimize consumer search costs should respond to the complex of consumer interests on both sides of a genericide case by tending towards standards rather than absolute rules. ${ }^{83}$ Trademark's fair use doctrine serves as an example. ${ }^{84}$ Under that doctrine, competitors are free to use descriptive terms that have acquired secondary meaning, but only in contexts in which they use those terms for their descriptive rather than their trademarked meaning, and only if the defendant uses the term in good faith. ${ }^{85}$ Whether that use is permissible will depend on the strength of the mark, the nature of the use and of the goods on which it was made, the defendant's use of a separate brand to identify and distinguish its own goods, and other factors. Courts applying the defense will tolerate some consumer confusion among the plaintiff's customers in order to permit the defendant's customers to easily find the products they are looking for, but the fact and extent of such confusion is relevant in deciding whether to permit the use. ${ }^{86}$

Something similar to the fair use doctrine might well serve consumers better than the all-or-nothing rule regarding genericide. Rather than immediately halting trademark protection as soon as fifty-one percent of the public views a former trademark as generic,

81. See Beebe, supra note 48 (noting the ability to hold several meanings for terms in the mind simultaneously); Deven R. Desai \& Sandra L. Rierson, Confronting the Genericism Conundrum, 28 Cardozo L. Rev. 1789, 1803 (2007) (stating that "trademarks function differently for different people in different contexts and are capable of different yet simultaneous uses"); Folsom \& Teply, supra note 75, 1339-42 (noting that many, and perhaps most, generic marks are hybrids with both trademark and generic meanings, and explaining the costs that such hybrids can impose on consumers).

82. See Jerre B. Swann, Genericism Rationalized, 89 TMR 639, 653 (1999) ("Consumer confusion is virtually a dictated consequence whenever a word used by one firm is declared generic ...”).

83. See also id. at 655 ("[T] $]$ he line between a fringe generic and a naturally descriptive term is far too thin and inconsequential to justify the expenditure of enormous judicial resources to ferret out its placement."); Vanessa Bowman Pierce, If It Walks Like a Duck and Quacks Like a Duck, Shouldn't It Be A Duck?: How a "Functional" Approach Ameliorates the Discontinuity Between the "Primary Significance" Tests for Genericness and Secondary Meaning, 37 N.M. L. Rev. 147 (2007).

84. 15 U.S.C. $§ 1115(b)(4)(2000)$.

85. See, e.g., Zatarain's, Inc., 698 F.2d at 791.

86. See KP Permanent Makeup Inc. v. Lasting Impression I, 543 U.S. 111 (2004) (finding that the fair use defense presupposes tolerating some confusion), on remand, KP Permanent Makeup Inc. v. Lasting Impression I, 408 F.3d 596 (9th Cir. 2005) (finding that confusion is still relevant in determining whether the fair use defense applies). 
the law could take a more case-by-case approach that focuses on the relationship between the plaintiff's interest and the defendant's use. If a substantial portion of the public still views the term as a trademark, but the majority views it primarily as a generic term, then both of these sets of consumers would benefit from an approach that allowed competitors to use the term in its generic sense, but prevented its use as a trademark by anyone other than the original trademark holder and required those who did use the term to try to avoid confusing consumers who thought of it as a mark. Courts, in other words, could permit uses of the generic term to describe the class of goods, while at the same time prohibiting competitors from adopting the term as a mark, or minimizing their own mark in an effort to confuse the consumers who still think of the mark as signifying a particular product. To be sure, courts today sometimes take steps to protect trademark owners in this situation-for example, by establishing rules requiring competitors who adopt a generic term that was once a protectable trademark to take steps to minimize confusion with the former mark owner. ${ }^{87}$ But the approach is neither systematically adopted nor consistent with the general thrust of genericide, which holds generic marks completely without protection. A better approach would recognize that the confusing use of even generic terms can constitute unfair competition under Section 43(a) of the Lanham Act ${ }^{88}$ when the generic term has trademark significance among some portion of the public and the defendant's use capitalizes on that trademark meaning. Cases like Genesee are on the right track in effectively treating genericide as a continuum rather than a threshold. 89

We think a standard rather than an absolute rule is also appropriate in those rare instances in which a term that was born generic comes over time to signify a single source of goods. From a search costs perspective, the situation is simply the inverse of genericide-a group of consumers have treated the term as generic, but over time another group-sometimes the vast majority-comes to understand it as a trademark. Microsoft's WINDOWS is an obvious example. There is good evidence that at the time Microsoft adopted the term in 1983, it was in general use

87. Genesee Brewing Co. v. Stroh Brewing Co., 124 F.3d 137, 150 (2d Cir. 1997) (concluding that plaintiff's mark Honey Brown for its ale was generic, but defendant could still be liable if it did not use "every reasonable means to prevent confusion" in using the generic term) (quoting Kellogg Co., 305 U.S. at 121); see also, e.g., Home Builders Ass'n v. L \& L Exhibition Mgmt., Inc., 226 F.3d 944, 950 (8th Cir. 2000); Forschner Group, Inc. v. Arrow Trading Co., 124 F.3d 402, 408-09 (2d Cir. 1997).

88. 45 U.S.C. $§ 1125(\mathrm{a})$ (2004).

89. Cf. Desai \& Rierson, supra note 81, at 1855 (contending that genericness determination should turn on mark's significance in the commercial marketplace, rather than in common language or parlance). 
to describe graphical user interface-based computer operating systems..$^{90}$ But by this century, the vast majority of computer users likely think of the term as signifying only Microsoft's operating system. Under current law, the only relevant question in such a case seems to be what consumers thought in 1983 when the term was adopted. ${ }^{91}$ But from a search costs perspective, marks should be able to lose their generic character as well as gain it, depending on the reactions of consumers. ${ }^{92}$ And just as the transition need not be an on-off switch for genericide, so too courts can apply a continuum in deciding whether a once-generic term has come over time to serve as a mark.

Treating genericness as a sliding scale rather than an absolute bar may have other salutary effects as well. Right now, trademark owners go to great lengths to prevent genericide. ${ }^{93}$ They constrain the way they use their mark, never treating it as a noun or a verb, but only as an adjective. ${ }^{94}$ They run advertisements to try to influence the way a mark is used in conversation. ${ }^{95}$ They send threatening or cajoling letters to dictionaries, newspapers, and artists, encouraging them to modify their use or description of a trademarked term. ${ }^{96}$ They have even come up with a (mythical) cause of action called "contributory dilution" that would allow them to sue dictionaries or ordinary citizens for misusing "their" term in dialogue. ${ }^{97}$ All of these expenditures are socially wasteful,

90. See, e.g., Microsoft Corp. v. Lindows.com, Inc., 2002 WL 32153471 (W.D. Wash. May 13, 2002).

91. Id. (marshalling evidence from that period).

92. See Anti-Defamation League of B'Nai B'Rith v. Arab Anti-Defamation League, 340 N.Y.S.2d 532, 543 (N.Y. Sup. 1972) (suggesting that generic term can acquire secondary meaning and thus become a protectable mark).

93. See Desai \& Rierson, supra note 81, at 1834-36 (making this point, and exploring in detail the socially wasteful expenditure of resources to avoid genericide).

94. This particular piece of advice, widespread in the trademark bar, appears to be based on a myth. No court has ever held a mark generic because it was used as a verb. See Rose A. Hagan, The Myths of Genericide, 22:2 ABA Intell. Prop. L. Newsletter 13 (2004), available at http://www.abanet.org/intelprop/bulletin/winter_04.pdf.

95. See, e.g., Robert P. Merges, Intellectual Property in the New Technological Age 679 (3d ed. 2003) (reproducing ad by Xerox corporation).

96. For one cartoonist's amusing response to such a letter, see http://extlab1.entnem.ufl.edu/IH8PCs/vol3/V3N2.html.

97. See Jerre B. Swann, The Validity of Dual Functioning Trademarks, Genericism Tested By Consumer Understanding Rather Than By Consumer Use, 69 TMR 357, 375 (1979). We want to emphasize that there is no such contributory dilution theory in the law today. No appellate court has ever adopted such a theory, and the Lanham Act provides no statutory support for the theory. See Lockheed Martin Corp. v. Network Solutions, Inc., 194 F.3d 980, 986 (9th Cir. 1999) (rejecting claim of "contributory dilution" and noting that no court has ever adopted it); Ty, Inc. v. Perryman, 306 F.3d 509, 512 (7th Cir. 2002) (noting that the caselaw doesn't support this broader conception of dilution, and questioning the desirability of creating such a doctrine); Freecycle Network v. Oey, 2007 WL 2781902 (9th Cir. Sept. 26, 2007) (there is no cause of action for "disparagement" of a mark by using it 
and if they are successful the resulting restraint on speech may do even more harm to society. They are a function of the mark owners' fear of the catastrophic loss of genericide. These expenditures would be largely unnecessary if courts were to adopt a fact-specific approach to genericide, because the focus would be on the defendant's use in context rather than on what the public or dictionaries say.

\section{Functionality}

The functionality doctrine, like the genericness doctrine, prevents parties from claiming trademark rights in a product feature that "is essential to the use or purpose of the article or if it affects the cost or quality of the article." 98 But while genericness generally applies to word marks, functionality applies to product configuration and occasionally packaging. Like genericness, functionality is a threshold rather than a linear variable in existing law. ${ }^{99}$ Even when consumers have come to associate a particular product feature with a single seller, that feature cannot serve as a trademark if exclusive use of it would put competitors at a non-reputation-related disadvantage. The U.S. Supreme Court recently emphasized, for example, that even if the public associates a particular feature with its first producer, the Lanham Act does not prevent others from copying that feature if it is part of what makes the product work. ${ }^{100}$

The connection between the functionality doctrine and a functioning market is even more fundamental than search costsconsumers cannot choose between competing products if one manufacturer can use a law designed to facilitate an efficient market to eliminate competing products altogether. Preventing trademark owners from protecting functional aspects of their

generally); but cf. Kegan v. Apple Computer, Inc., 1996 WL 667808 (N.D. Ill. 1996) (finding genuine issue of fact as to contributory dilution claim, suggesting that "encouragement" of dilution could constitute contributory dilution). Still, the fact that the argument is made is a testament to the lengths to which trademark owners will go to try to avoid genericide.

98. TrafFix Devices, Inc., 532 U.S. at 32-33 (quoting Qualitex, 514 U.S. at 165). Strictly speaking, after Congressional action in the late 1990s functionality is no longer a defense but rather a part of a trademark owner's affirmative case in actions brought under $\S 43(\mathrm{a})$. 15 U.S.C. $§ 1125$ (a)(3); see Tumblebus Inc. v. Cranmer, 399 F.3d 754, 768 (6th Cir. 2005).

99. But also like genericide, there is some support for preventing confusing uses under section 43(a) in a few cases that find functionality but are concerned with the confusion that might result. See Graeme B. Dinwoodie, The Death of Ontology: A Teleological Approach to Trademark Law, 84 Iowa L. Rev. 611, 746-51 (1999).

100. See TrafFix Devices, Inc., 532 U.S. at 34-35 ("The Lanham Act . . does not protect trade dress in a functional design simply because an investment has been made to encourage the public to associate a particular functional feature with a single manufacturer or seller."). On the contours of trademark functionality doctrine, see Mark Alan Thurmon, The Rise and Fall of Trademark Law's Functionality Doctrine, 56 Fla. L. Rev. 243 (2004); Robert C. Denicola, Freedom to Copy, 108 Yale L.J. 1661, 1670-74 (1999). 
products is therefore consistent with a search costs rationale. Indeed, one might think of it as a precondition to consumer search. While this is easiest to see with technological functionalityimagine the seller of a wheel claiming the round design as a trademark and preventing competitors from making round wheels-it is also true of aesthetic functionality. ${ }^{101}$ A design feature is aesthetically functional if it causes the product to be more desirable not because of a reputational connection, but because it is intrinsically attractive. Many goods are purchased on aesthetics in whole or in part. Allowing someone who develops an attractive style of painting or a sleek design for a product to prevent others from using it interferes with the market for the product and generally serves no trademark-related purpose.

As with genericide, however, there is a problem. Because functional characteristics, aesthetic appeal, and source-identifying information may sometimes be lumped together in the same product-think of the Ferrari ${ }^{102}$ - strict application of the functionality doctrine also has the potential to increase rather than decrease consumer search costs in some cases. ${ }^{103}$ When a functional product feature has achieved secondary meaning, for example, some consumers might assume that all products with that feature come from a single source. If others can copy that feature, those who make such an assumption will be confused; if not, those who just want the product for its intrinsic value will lose the benefit of competition to produce the product. ${ }^{104}$

Unlike genericide, a sliding scale is harder to imagine with functional products because the consumer interest in use of the product is not simply avoiding confusion as to source, but access to the product itself. But that doesn't mean that nothing can be done

101. See Abercrombie \& Fitch, 537 F.2d at 9.

102. See Ferrari S.p.A. Esercizio v. Roberts, 944 F.2d 1235, 1246-47 (6th Cir. 1991) (holding that the exterior design of the Ferrari is nonfunctional).

103. See Peter E. Mims, Note, Promotional Goods and the Functionality Doctrine: An Economic Model of Trademarks, 63 Tex. L. Rev. 639, 658-59 (1984) (recognizing the role that the functionality doctrine plays in lowering search costs, but arguing that the doctrine of aesthetic functionality interferes with that role). For academic commentary on the functionality doctrine and the tradeoffs it embodies, see Maury Audet, Wilhelm Pudenz v. Littlefuse, Inc.: Next Replace Misnomer "Incontestable" with "Conclusive," 40 Idea 473, 48387 (2000); Graeme B. Dinwoodie, The Death of Ontology: A Teleological Approach to Trademark Law, 84 Iowa L. Rev. 611, 699-701 (1999); Thurmon, supra note 100, at 244-53.

104. Robert Bone points out that courts in functionality cases have to decide between two different economic costs: the increase in consumer search costs if the trade dress is denied protection, balanced against the increase in price that might occur if the originator has exclusive rights over the product feature. See Bone, supra note 9, at 2180 ("The goal of the functionality doctrine is to strike a balance between limiting the acquisition of market power and reducing information-related consumer harms. This means that a functionality analysis should tolerate market power over price when doing so is justified by the information-related consumer harms that trade dress protection avoids."). 
to limit the potentially confusing consequences of a finding of functionality. As with some cases involving generic marks, some courts have responded to these risks not by prohibiting use of the feature, but by requiring competitors to "use reasonable care to inform the public of the source of [their] product[s]." ${ }^{105}$ To the extent that the use may even then mislead some members of the public, the functionality doctrine presupposes that the harm to consumers in these cases is outweighed by the greater availability of competitive products in the first place. Given what is at stake, that seems to us the right balance.

\section{Abandonment}

Trademarks are protected so long as the mark owner uses them in commerce. When use stops for good, the trademark is deemed abandoned. ${ }^{106}$ The abandonment rule is designed to release marks back to the public for use by others, preventing companies from "warehousing" marks. ${ }^{107}$ But releasing marks back to the open market can have a rather significant negative impact on consumer search. If a company builds up substantial goodwill before going out of business, that goodwill will often persist long after the company and its products disappear. The abandonment rule, and in particular the three-year presumption of abandonment, permits new trademark owners to capitalize on that goodwill, creating confusion or at the least causing cognitive dissonance within the minds of consumers who remember a mark as signifying one product and must now relearn it as signifying a different product in the same field. Examples abound, and include the reappearance of both FRONTIER and PAN AM as airline names and a race to claim DURAFLAME as a trademark for fake fire logs. ${ }^{108}$

To be sure, some-though hardly all-courts seem willing to avoid finding abandonment based on an involuntary cessation of business, and continuing goodwill in the mark is one reason they

105. Gum, Inc. v. Gumakers of Am., Inc., 136 F.2d 957, 960 (3d Cir. 1943) (citing Kellogg Co., 305 U.S. at 120); Am. Greetings Corp. v. Dan-Dee Imps., Inc., 807 F.2d 1136, 1141 (3d Cir. 1986) ("[I]f the functional feature or combination is also found to have acquired secondary meaning, the imitator may be required to take reasonable steps to minimize the risk of source confusion.”); $c f$. Am. Fork \& Hoe Co. v. Stampit Corp., 125 F.2d 472, 475 (6th Cir. 1942) (" $[\mathrm{I}] \mathrm{n}$ order to establish even the limited right of compelling appellant to take positive steps to avoid confusion, the existence of secondary meaning must plainly appear.").

106. 15 U.S.C. § 1127 (providing that abandonment occurs when "use has been discontinued with intent not to resume such use," or when the mark hasn't been used for three years).

107. See Major League Baseball Properties, Inc. v. Sed Non Olet Denarius, Ltd., 817 F. Supp. 1103 (S.D.N.Y. 1993).

108. California Cedar Prods. Co. v. Pine Mountain Corp., 724 F.2d 827 (9th Cir. 1984). 
do so. ${ }^{109}$ But those courts do so only when a company ceases business involuntarily, and under the statutory framework they can do even that only for three years. Goodwill in a major mark can persist long after that, particularly in cases where a company changes its name but continues in business. Federal Express changed its name to FedEx several years back, and it is the new name that appears on the website and on all packaging. But it is doubtful that consumers would benefit should the name be deemed abandoned, permitting a competitor to use it. ${ }^{110}$

The statutory framework seems to serve little purpose within the search costs framework, and can affirmatively increase consumer search costs. The statute should be revised to preclude others from adopting a mark in any case in which significant brand recognition remained in the old name, even after it is abandoned. ${ }^{111}$ The result may be that no one is entitled to use a particular mark after a well-known owner abandons it, but that result is the one that is least likely to confuse consumers. ${ }^{112}$

\section{CONCLUSION}

Economists have long recognized that the goal of facilitating the free exchange of goods requires consumers to be able to find what they are looking for quickly and cheaply. Reducing consumer search costs, in turn, is the primary traditional justification-and still the best one-for having trademark law. What we have shown in this article is that the search-costs rationale justifies not only the affirmative rights trademark law confers, but also the limits the law places on those rights. To a large extent, existing doctrine is consistent with trademark theory. But a few doctrines-notably

109. See, e.g., Pan Am. World Airways, Inc. v. Panamerican Sch. of Travel, Inc., 648 F. Supp. 1026, 1031 (S.D.N.Y.), aff'd, 810 F.2d 1160 (2d Cir. 1986); Am. Int'l Group v. American Int'l Airways, Inc., 726 F. Supp. 1470 (E.D. Pa. 1989). But see Major League Baseball, 817 F. Supp. at 1128-29 \& n.20 (refusing to protect BROOKLYN DODGERS mark after the team's move to Los Angeles despite presence of significant name recognition).

110. In fact, FedEx has likely retained some use of the FEDERAL EXPRESS mark to avoid just such an outcome. Whether that will be effective is open to question, though. See Exxon v. Humble Exploration, Inc., 695 F.2d 96 (5th Cir. 1983) (finding that a token continuing use of Humble Oil name after name change was not sufficient to avoid abandonment).

111. Cf. Stanley A. Bowker, Jr., Note, The Song Is Over But the Melody Lingers On: Persistence of Goodwill and the Intent Factor in Trademark Abandonment, 56 Fordham L. Rev. 1003, 1006-07 (1988).

112. There is some question who would enforce such a right in the case of common-law usage as opposed to an effort to register the abandoned mark. We believe the former owner of the abandoned mark should have a right to seek injunctive relief, but not damages, in such a case. While one might reasonably wonder whether a company that abandoned the mark would have any such incentive, the fact that there are a sizeable number of cases involving abandoned marks suggests that, for whatever reason, they often do. 
genericness and abandonment-can have the unintended consequence of increasing rather than reducing consumer search costs. We suggest ways those doctrines can be modified so all aspects of trademark law - the grant of rights and the limitation on those rights-serve the purposes of that law. 